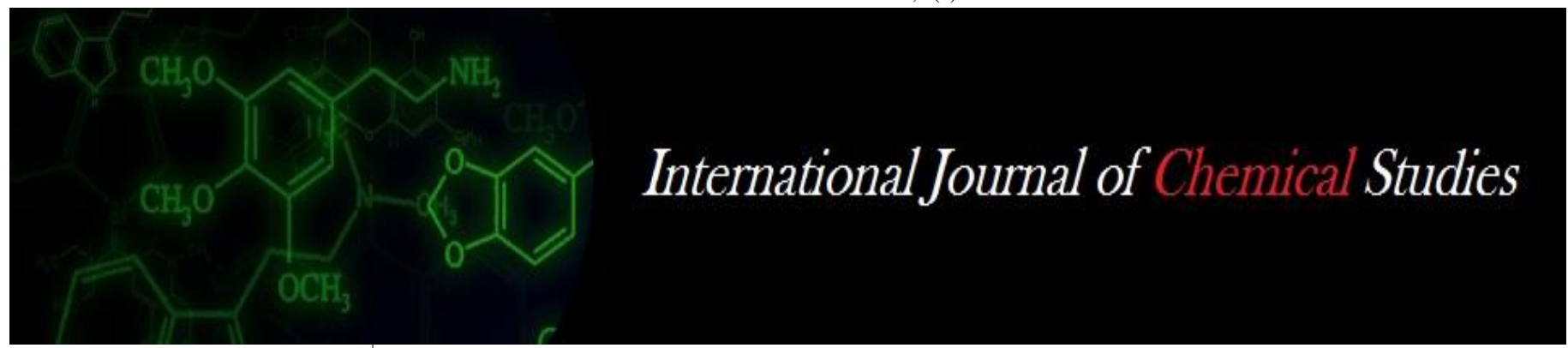

P-ISSN: 2349-8528

E-ISSN: 2321-4902

www.chemijournal.com

IJCS 2020; 8(6): 2529-2532

(C) 2020 IJCS

Received: 23-09-2020

Accepted: 29-10-2020

\section{DS Bankar}

Department of Agriculture

Meteorology, VNMKV,

Parbhani, Maharashtra, India

SB Pawar

NARP, Aurangabad,

Maharashtra, India

\section{GB Raut}

Department of Agriculture

Meteorology, VNMKV,

Parbhani, Maharashtra, India

\section{Studies on effect of weather parameters on green gram (Vigna radiate $L$.) varieties under different sowing dates}

\author{
DS Bankar, SB Pawar and GB Raut
}

DOI: $\underline{\text { https://doi.org/10.22271/chemi.2020.v8.i6aj.11152 }}$

\begin{abstract}
The experiment was conducted on experimental farm at Department of Agricultural Meteorology, College of Agriculture, Vasantrao Naik Marathwada Krishi Vidyapeeth, Parbhani, during Kharif season 2017 entitled "Influence of weather parameters on growth and yield of different genotypes of green gram (vigna radiata. L) under different sowing dates" to study the relationship between meteorological parameters and different sowing dates and its impact on yield of different genotypes green gram. The experiment was conducted in Spilt plot design with three replications. Treatments comprised of four sowing dates in main plot $\mathrm{D}_{1} 24^{\text {th }} \mathrm{MW}, \mathrm{D}_{2} 26^{\text {th }} \mathrm{MW}, \mathrm{D}_{3} 28^{\text {th }} \mathrm{MW}$ and $\mathrm{D}_{4} 30^{\text {th }} \mathrm{MW}$ with four varieties in sub plot viz. Vaibhav, BM-4, BM-2002-1 and BM-2003-2. The results obtained from the experiment revealed that all the biometric observations plant height, number of functional leaves, number of branches, dry matter, number of pods, pod length, number of seeds $\operatorname{pod}^{-1}$ in kharif green gram were significantly highest in $\mathrm{D}_{1} 24^{\text {th }} \mathrm{MW}\left(16^{\text {th }} \mathrm{June}\right)$ followed by $\mathrm{D}_{2} 26^{\text {th }} \mathrm{MW}\left(30^{\text {th }} \mathrm{June}\right), \mathrm{D}_{3} 28^{\text {th }}\left(14^{\text {th }} \mathrm{July}\right)$ and $\mathrm{D}_{4} 30^{\text {th }} \mathrm{MW}$ (28 $8^{\text {th }}$ July) respectively. The green gram variety BM-2003-2 was found to be highly productive as compared to Vaibhav, BM-4, and BM-2002-1.
\end{abstract}

Keywords: Green gram, varieties, dates of sowing, weather parameter and yield

\section{Introduction}

Green gram (Vigna radiata L. Wilczek) is one of the most important pulse crops of global economic importance. It is locally called as moong or mug and belongs to the family Leguminoceae, it fixes atmospheric nitrogen and improves soil fertility by adding $20-25 \mathrm{~kg} \mathrm{~N}$ $\mathrm{ha}^{-1}$. It has yield potential of around $2000 \mathrm{~kg} / \mathrm{ha}^{-1}$ but productivity is low $\left(864 \mathrm{~kg} / \mathrm{ha}^{-1}\right)$. (Md Tariqul Islam, 2015) ${ }^{[5]}$. Mung bean has originated in India and is a native of India and central Asia. It is grown in these areas since prehistoric period. In India green gram is mostly grown in Andhra Pradesh, Maharashtra, Orissa, Rajasthan, Gujarat, Madhya Pradesh, Punjab and Uttar Pradesh. (Vakeswaran et al., 2016) ${ }^{[12]}$. Green gram (Vigna radiata L.) is a good source of high quality protein. It contains protein $(25 \%)$, fats $(1.5 \%)$, minerals $(3.5 \%)$, fibre $(4.1 \%)$ and carbohydrates (56.7). It also has remarkable quality of ascorbic acid when sprouted and also bear riboflavin $(0.2 \mathrm{mg} / 100 \mathrm{gm})$. It also contains minerals $(3.54 \%)$, calcium $(0.12 \%)$ and 334 Kcal of energy from $100 \mathrm{~g}$ of grain. Green gram can also be used as a cattle feed. After harvesting the pods, green plants are uprooted or cut from ground level and chopped into small pieces and fed to cattle. The seed husks can be soaked in water and used as cattle feed. Green gram being a leguminous crop, it has the capacity to fix the atmospheric nitrogen. Green gram is also used as green manure crop. It also helps in preventing soil erosion. It is a short duration crop. Being a short duration crop, it fits well in many intensive crop rotations (Bhowmick et al., 2006) ${ }^{[2]}$. The weather parameters play an important role in deciding the success or failure of the crop, because they strongly influence the physiological expression and genetic potential of the crop. Solar radiation, temperature, soil moisture, relative humidity and bright sunshine hours are the important weather elements that influence the crop life cycle during growing season. (Pradeep Makone et al., 2015) ${ }^{[8]}$. The optimum time is mainly dependent on prevailing agro-climatic conditions of an area besides the variety grown. Planting during the optimum period, therefore ensures better harmony between the plant and weather which ultimately results in higher crop yields (Venkateswarulu et al., 1991) ${ }^{[13]}$
DS Bankar

Department of Agriculture

Meteorology, VNMKV,

Parbhani, Maharashtra, India 


\section{Material and Methods}

The field experiment was conducted during the Kharif 2017 at Research farm of Department of Agricultural Meteorology, college of Agriculture Parbhani. The experiment was laid out in Spilt plot design with three replications. Treatments comprised of four sowing dates in main plot $\mathrm{D}_{1} 24^{\text {th }} \mathrm{MW}, \mathrm{D}_{2}$ $26^{\text {th }} \mathrm{MW}, \mathrm{D}_{3} 28^{\text {th }} \mathrm{MW}$ and $\mathrm{D}_{4} 30^{\text {th }} \mathrm{MW}$ with four varieties in sub plot viz. Vaibhav, BM-4, BM-2002-1 and BM-2003-2. Gross and net plot sizes were $4.8 \times 4.3 \mathrm{~m}^{2}$ and $4.2 \times 3.9 \mathrm{~m}^{2}$, respectively. Sowing was done by dibbling method with spacing of row to row and plant to plant $30 \times 10 \mathrm{~cm}$. To maintain optimum plant population gap filling and thinning was carried out 10 and 15 days after sowing by keeping only one healthy seedling hill-1. The soil analyzed in experimental field selected for experiment is uniform with typical medium soil having medium fertility and fairly good drainage. Preharvested Biometric observations Emergence count, Final plant stand, Height of plant $(\mathrm{cm})$, Number of leaves plant ${ }^{-1}$, Number of branches plant ${ }^{-1}$, Dry matter plant ${ }^{-1}$, Days to $50 \%$ flowering was taken on 15 DAS and subsequent observations were recorded at an interval of 15 days. Postharvest observations Number of pods plant ${ }^{-1}$, Pod Length, Grain yield plant $^{-1}(\mathrm{~g})$, Grain yield plot $^{-1}(\mathrm{~kg})$, Grain yield ha' ${ }^{-1}$, Straw yield plot $^{-1}(\mathrm{~kg})$, Straw yield ha ${ }^{-1}$, Biological yield plot ${ }^{-1}(\mathrm{~kg})$, Test weight, Harvest index $(\%)$ recorded At time of harvest. Meteorological Observations Maximum temperature $\left({ }^{0} \mathrm{C}\right)$, Minimum temperature $\left({ }^{0} \mathrm{C}\right)$, Rainfall $(\mathrm{mm})$, Rainy days, Relative humidity (\%), Winds speed $(\mathrm{km} / \mathrm{hr})$, Bright sunshine hours (hrs) recorded daily.

\section{Results and Discussion Growth studies \\ Plant height}

Data in Table (1) revealed that the mean plant height was significantly influenced by different sowing dates and variety. The plant height was found to be highest in first date of sowing $\mathrm{D}_{1} 24^{\text {th }} \mathrm{MW}$ i.e. $(59.13 \mathrm{~cm})$ at the time of harvest as compared to other sowing dates. Lowest plant height was recorded in $\mathrm{D}_{4} 30^{\text {th }} \mathrm{MW}$ during all growth stages of crop. The possible reason could be that the early sowing date $D_{1} 24^{\text {th }}$ MW of green gram crop had longer period for growth and development as compared to $\mathrm{D}_{2} 26^{\text {th }} \mathrm{MW}, \mathrm{D}_{3} 28^{\text {th }} \mathrm{MW}$ and $\mathrm{D}_{4}$ $30^{\text {th }}$ MW sowing dates. Therefore, plant height reduced subsequently with delayed sowing. Similar results was obtained by Malik et al. (2003) ${ }^{[6]}$. The variety $\mathrm{V}_{4}$ BM-2003-2 was found significantly superior among all varieties producing taller plant up to harvest. Interaction effect the mean plant height was non-significantly by sowing dates and varieties at all growth stages.

\section{Number of functional leaves plant ${ }^{-1}$}

Data in Table (1) revealed that the Number of functional leaves plant ${ }^{-1}$ was significantly influenced by different sowing dates and variety. The crop sown on $\mathrm{D}_{1} 24^{\text {th }} \mathrm{MW}$ significantly produced higher number of functional leaves plant $^{-1}$ at 45 days after sowing i.e. (8.43) leaves and at harvest it reduced upto (5.72). In the present study higher number of leaves was obtained in $D_{1} 24^{\text {th }} \mathrm{MW}$ which may be due to favorable environmental factors (temperature, rainfall and relative humidity etc.) Plant growth is strongly related to its genetic characteristics and is influenced by various environmental conditions. Similar results obtained by Malik et al. (2003) ${ }^{[6]}$. The variety $V_{4}$ BM-2003-2 was found to be superior in producing maximum number of leaves plant $^{-1}$ i.e (8.02) over the varieties. Similar results was obtained by Singh et al.
(2010) ${ }^{[10]}$. Interaction effect Mean number of leaves plant ${ }^{-1}$ was non-significantly by sowing dates and varieties during different crop growth stages.

\section{Number of branches plant ${ }^{-1}$}

Data in Table (1) revealed that the number of branches plant ${ }^{-1}$ was significantly influenced by different sowing dates and variety. Highest mean no. of branches plant ${ }^{-1}$ was recorded in $\mathrm{D}_{1} 24^{\text {th }} \mathrm{MW}$ i.e (7.35) all other sowing dates. The probable reason for this may be suitable rainfall, rainy day and relative humidity at branching stage of $\mathrm{D}_{1} 24^{\text {th }} \mathrm{MW}$ date of sowing. The variety $V_{4}$ BM-2003-2 recorded highest number of branches plant ${ }^{-1}$ i.e (7.30) was significantly superior over the variety. The probable reason for this may be the genetic potential of the genotype that has helped in producing more number of braches plant ${ }^{-1}$. Similar result obtained by Bhise et al. (2010) ${ }^{[1]}$. The number of branches produced plant ${ }^{-1}$ nonsignificantly the interaction effect of sowing dates and varieties.

\section{Total dry matter production plant $^{-1}(\mathrm{~g})$}

Data in Table (1) revealed that the total dry matter production plant $^{-1}(\mathrm{~g})$ was significantly influenced by different sowing dates and variety. The mean total dry matter accumulation per plant was significantly influenced by sowing dates at different stages of crop growth. The treatment $\mathrm{D}_{1} 24^{\text {th }} \mathrm{MW}$ produced higher dry matter plant ${ }^{-1}(12.19 \mathrm{~g})$. The lowest dry matter plant ${ }^{-1}$ was produced in $\mathrm{D}_{4} 30^{\text {th }} \mathrm{MW}$ sowing date. $\mathrm{D}_{1} 24^{\text {th }} \mathrm{MW}$ sowing date accumulated highest dry matter due to favorable weather conditions i.e. solar radiation, bright sun shine hours, rainfall and relative humidity etc. during crop growing period than other sowing dates. Due to delayed sowing the rate of photosynthesis, biomass production, seed set and grain yield in crop growth stages was reduced which ultimately affected the total dry matter production. Similar result was reported by Nisar and khan (2003) [7]. The variety $\mathrm{V}_{4}$ BM-2003-2 produced maximum dry matter plant ${ }^{-1}$ i.e $(12.05 \mathrm{~g})$ at all stages of crop. The interaction effect between sowing dates and varieties was found to be non-significant at all stages of crop.

\section{Days to $50 \%$ flowering}

Data in Table (1) revealed that the Days to $50 \%$ flowering was significantly influenced by different sowing dates and variety. The highest days to $50 \%$ flowering was observed in $\mathrm{D}_{2} 26^{\text {th }}$ MW about 40 days and lowest was observed in $\mathrm{D}_{3} 28^{\text {th }}$ MW about 35 days. The earlier sown crop required more time to attain $50 \%$ flowering. Whereas, late sown crop required less time to attain $50 \%$ flowering. The number of days required to attain $50 \%$ flowering decreased with delay in sowing dates. This is attributable to the prevalence of higher temperature, soil moisture stress and more bright sunshine hours in delayed sowings as compared initial sowing. Days to $50 \%$ flowering was highest in variety $\mathrm{V}_{1}$ Vaibhav i.e. 39 days and lowest in $\mathrm{V}_{2}$ BM-4 i.e. 36 days for flowering. Similar result obtained by Choudhary et al. (1989) ${ }^{[3]}$. The interaction effect between sowing dates and varieties was found to be non-significant at all stages of crop.

\section{Number of pods plant ${ }^{-1}$}

Data in Table (1) revealed that the Number of pods plant ${ }^{-1}$ was significantly influenced by different sowing dates and variety. The maximum number of pods plant $^{-1}$ were observed with the crop sown on $\mathrm{D}_{1} 24^{\text {th }} \mathrm{MW}$ which was produced (9.68) pods plant ${ }^{-1}$. It was found that delayed sowing of green 
gram crop caused decrease in number of pods plant ${ }^{-1}$. The reason could be that the early sown crop got optimum conditions during growing period while the late sown crop was adversely affected. Similar result was reported by Rana et al. (2006) ${ }^{[9]}$. In variety higher number of pods plant ${ }^{-1}$ was produced by $\mathrm{V}_{4}$ BM-2003-2 i.e. (9.83). The interaction effect between sowing dates and varieties was found to be nonsignificant at all stages of crop.

\section{Post harvest studies}

\section{Seed yield $\left(\mathrm{kg} \mathrm{ha}^{-1}\right)$}

Data in Table (2) revealed that the mean seed yield was (736 $\mathrm{kg} / \mathrm{ha}^{-1}$ ) which significantly influenced by different sowing dates and varieties. The crop sown on $\mathrm{D}_{1} 24^{\text {th }} \mathrm{MW}$ produced highest seed yield $\left(970 \mathrm{~kg} / \mathrm{ha}^{-1}\right)$ yield decreased with delay in sowing. Reduction in the seed yield might be due to adverse effects of weather parameters particularly rainfall, temperature and relative humidity on the growth and development of the crop. Generally the variations in meteorological parameters at different sowing dates exert their influence on the plant growth and ultimately yield. The early attainment of flowering under delayed sowing i.e. $\mathrm{D}_{3}$ $28^{\text {th }} \mathrm{MW}$ and $\mathrm{D}_{4} 30^{\text {th }} \mathrm{MW}$ sowing dates brought about significant reduction in biomass production affecting the yield of crop. Similar result observed by Taleei et al. (1999) and Devidas et al. (2014) ${ }^{[11,4]}$. The variety $\mathrm{V}_{4}$ BM-2003-2 produced maximum seed yield $\left(819 \mathrm{~kg} / \mathrm{ha}^{-1}\right)$ which was significantly superior over other varieties. The interaction effect between sowing dates and varieties was found to be non-significant at all stages of crop.

Table 1: Periodical mean growth and yield attributing characters of green gram as influenced by different treatments

\begin{tabular}{|c|c|c|c|c|c|c|}
\hline Treatment & \begin{tabular}{|c|}
$\begin{array}{c}\text { Plant height } \\
\text { (cm) }\end{array}$ \\
\end{tabular} & $\begin{array}{c}\text { No. of leaves } \\
\text { plant }^{-1}\end{array}$ & $\begin{array}{c}\text { No. of branches } \\
\text { plant }^{-1}\end{array}$ & \begin{tabular}{|c|} 
Dry matter production plant \\
${ }^{-}(\mathrm{g})$.
\end{tabular} & $\begin{array}{l}\text { Days to 50\% } \\
\text { flowering }\end{array}$ & $\begin{array}{c}\text { No. of pods } \\
\text { plant }^{-1}\end{array}$ \\
\hline \multicolumn{7}{|c|}{ Sowing dates $(\mathrm{D})$} \\
\hline $\mathrm{D}_{1}: 24^{\text {th }} \mathrm{MW}$ & 59.13 & 8.43 & 7.35 & 12.19 & 38.00 & 9.68 \\
\hline $\mathrm{D}_{2}: 26^{\text {th }} \mathrm{MW}$ & 49.62 & 7.43 & 6.48 & 12.03 & 40.00 & 9.03 \\
\hline $\mathrm{D}_{3}: 28^{\text {th }} \mathrm{MW}$ & 45.00 & 6.43 & 5.30 & 11.19 & 35.00 & 7.90 \\
\hline $\mathrm{D}_{4}: 30^{\text {th }} \mathrm{MW}$ & 27.05 & 6.03 & 4.54 & 10.83 & 37.00 & 6.40 \\
\hline $\mathrm{SE} \pm$ & 1.33 & 0.21 & 0.19 & 0.34 & 0.62 & 0.26 \\
\hline $\mathrm{CD}$ at $5 \%$ & 4.59 & 0.71 & 0.66 & 1.16 & 1.82 & 0.89 \\
\hline \multicolumn{7}{|c|}{ Varieties (V) } \\
\hline $\mathrm{V}_{1}$ : Vaibhav & 42.13 & 6.69 & 5.35 & 11.15 & 39.00 & 8.03 \\
\hline $\mathrm{V}_{2}: \mathrm{BM}-4$ & 41.83 & 6.27 & 5.23 & 11.01 & 36.00 & 6.61 \\
\hline $\mathrm{V}_{3}: \mathrm{BM}-2002-1$ & 45.99 & 7.05 & 5.80 & 11.93 & 37.50 & 8.55 \\
\hline $\mathrm{V}_{4}: \mathrm{BM}-2003-2$ & 50.85 & 8.02 & 7.30 & 12.05 & 37.50 & 9.83 \\
\hline $\mathrm{SE} \pm$ & 1.28 & 0.43 & 0.36 & 0.29 & 0.75 & 0.21 \\
\hline CD at $5 \%$ & 3.83 & 1.29 & 1.07 & 0.86 & 2.19 & 0.63 \\
\hline \multicolumn{7}{|c|}{ Interaction (D X V) } \\
\hline $\mathrm{SE} \pm$ & 3.51 & 1.10 & 0.75 & 0.12 & 1.50 & 0.80 \\
\hline $\mathrm{CD}$ at $5 \%$ & NS & NS & NS & NS & NS & NS \\
\hline Mean & 45.20 & 7.04 & 5.92 & 11.54 & 37.50 & 8.25 \\
\hline
\end{tabular}

Table 2: Yield and yield attributes of green gram varieties under different treatments

\begin{tabular}{|c|c|c|c|c|}
\hline Treatment & Seed yield $\left(\mathrm{kg} \mathrm{ha}^{-1}\right)$ & Straw yield $\left(\mathrm{kg} \mathrm{ha}^{-1}\right)$ & Biological yield $\left(\mathrm{kg} \mathrm{ha}^{-1}\right)$ & Harvest index (\%) \\
\hline \multicolumn{5}{|c|}{ Sowing dates (D) } \\
\hline $\mathrm{D}_{1}: 24^{\text {th }} \mathrm{MW}$ & 970 & 2060 & 3030 & 32.02 \\
\hline $\mathrm{D}_{2}: 26^{\text {th }} \mathrm{MW}$ & 910 & 1949 & 2859 & 31.82 \\
\hline $\mathrm{D}_{3}: 28^{\text {th }} \mathrm{MW}$ & 642 & 1529 & 2171 & 29.58 \\
\hline $\mathrm{D}_{4}: 30^{\text {th }} \mathrm{MW}$ & 421 & 1088 & 1508 & 27.85 \\
\hline $\mathrm{SE} \pm$ & 22.74 & 50.06 & 69.61 & 0.91 \\
\hline $\mathrm{CD}$ at $5 \%$ & 78.69 & 173.25 & 240.90 & 3.13 \\
\hline \multicolumn{5}{|c|}{ Varieties (V) } \\
\hline $\mathrm{V}_{1}$ : Vaibhav & 703 & 1625 & 2322 & 29.81 \\
\hline $\mathrm{V}_{2}: \mathrm{BM}-4$ & 666 & 1596 & 2270 & 28.93 \\
\hline $\mathrm{V}_{3}: \mathrm{BM}-2002-1$ & 753 & 1652 & 2391 & 31.20 \\
\hline $\mathrm{V}_{4}: \mathrm{BM}-2003-2$ & 819 & 1753 & 2585 & 31.33 \\
\hline $\mathrm{SE} \pm$ & 18.19 & 41.87 & 61.05 & 0.57 \\
\hline $\mathrm{CD}$ at $5 \%$ & 54.55 & 125.53 & 183.03 & 1.70 \\
\hline \multicolumn{5}{|c|}{ Interaction (D X V) } \\
\hline $\mathrm{SE} \pm$ & 47.96 & 64.49 & 167.03 & 0.41 \\
\hline $\mathrm{CD}$ at $5 \%$ & NS & NS & NS & NS \\
\hline Mean & 736 & 1656 & 2392 & 30.32 \\
\hline
\end{tabular}

\section{Straw yield (Kg ha $\left.{ }^{-1}\right)$}

Data in Table (2) revealed that the Straw yield $\left(\mathrm{Kg} / \mathrm{ha}^{-1}\right)$ was significantly influenced by different sowing dates and variety. The mean straw yield of green gram was about $\left(1656 \mathrm{~kg} / \mathrm{ha}^{-1}\right)$. The sowing on $\mathrm{D}_{1} 24^{\text {th }}$ MW produced highest yield 2060 $\mathrm{kg} / \mathrm{ha}^{-1}$ straw yield which was superior over the other sowing dates. Similar result observed by Taleei et al. (1999) ${ }^{[11]}$. The straw yield was significantly influenced by different varieties. Maximum straw yield $\left(1753 \mathrm{~kg} / \mathrm{ha}^{-1}\right)$ was observed in variety $\mathrm{V}_{4}$ BM-2003-2 which was significantly superior over the variety The interaction effect between sowing dates and varieties was found to be non-significant at all stages of crop. 


\section{Biological yield ( $\left.\mathrm{Kg} \mathrm{ha}^{-1}\right)$}

Data in Table (2) revealed that Biological yield $\left(\mathrm{Kg} / \mathrm{ha}^{-1}\right)$ was significantly influenced by different sowing dates and variety. The average biological yield was $\left(2392 \mathrm{~kg} / \mathrm{ha}^{-1}\right)$. The sowing $\mathrm{D}_{1} 24^{\text {th }} \mathrm{MW}$ recorded highest biological yield $\left(3030 \mathrm{~kg} / \mathrm{ha}^{-1}\right)$. The highest biological yield of green gram in $\mathrm{D}_{1} 24^{\text {th }} \mathrm{MW}$ date of sowing might be because of environmental conditions favorable for proper grain filling and dry matter accumulation as compared to other sowing dates. Similar result observed by Taleei et al. (1999) [11]. Maximum biological yield was observed in variety $\mathrm{V}_{4}$ BM-2003-2 i.e. (2585 kg/ha-1) which was significantly superior over variety. The interaction effect between sowing dates and varieties was found to be nonsignificant at all stages of crop.

\section{Harvest Index (\%)}

Data in Table (2) revealed that the mean harvest index of green gram was $(30.32 \%)$ It was influenced due to sowing dates and varieties. The sowing of crop at $\mathrm{D}_{1} 24^{\text {th }} \mathrm{MW}$ recorded higher $(32.02 \%)$ harvest Index over other sowing dates. The highest harvest index was recorded by variety $\mathrm{V}_{4}$ BM-2003-2 i.e. (31.33\%) than rest of the three varieties. Same result was reported by Rana et al. (2006) ${ }^{\text {[9] }}$. The interaction effect between sowing dates and varieties was found to be non-significant at all stages of crop.

\section{Conclusion}

On the basis of the field experimentation conducted, it could be concluded that among different sowing dates, the sowing of green gram crop at $\mathrm{D}_{1} 24^{\text {th }} \mathrm{MW}$ was found to be optimum for achieving higher seed yield $\left(970 \mathrm{~kg} / \mathrm{ha}^{-1}\right)$ followed by $\mathrm{D}_{2}$ $26^{\text {th }} \mathrm{MW}\left(910 \mathrm{~kg} / \mathrm{ha}^{-1}\right), \mathrm{D}_{3} 28^{\text {th }} \mathrm{MW}\left(642 \mathrm{~kg} / \mathrm{ha}^{-1}\right)$ and $\mathrm{D}_{4} 30^{\text {th }}$ MW (421 kg/ha-1). The green gram variety $\mathrm{V}_{4}$ BM-2003-2 highest seed yield about $\left(819 \mathrm{~kg} / \mathrm{ha}^{-1}\right)$ was found to be highly productive as compared to $\mathrm{V}_{3} \mathrm{BM}-2002-1\left(753 \mathrm{~kg} / \mathrm{ha}^{-1}\right), \mathrm{V}_{1}$ Vaibhav (703 kg/ha-1) and $\mathrm{V}_{2}$ BM-4 $\left(666 \mathrm{~kg} / \mathrm{ha}^{-1}\right)$.

\section{References}

1. Bhise AB, Solunke SS, Pawar SV, Alse UN, Kadam GT. Effect of varieties and plant geometry on yield attribute of summer green gram. Advanced journal of crop improvement 2010;2:21-223.

2. Bhowmick MK, Sadukhan R, Gupta S. Comparative performance of mungbean genotypes under varying plant population and fertilizer levels during Kharif Indian J. Pulses Res 2006;19(2):225-227.

3. Choudhary DC, Singh RP, Singh NP. Productivity of urdbean varieties as influenced by planting dates. Legume Research 1989;12(1):43-44.

4. Devidas M, Ransing AK, Verma MR, Meshram, Paikra PR. Nodulation, yield and thermal requirement of mungbean (Vigna radiata L.) genotypes as influenced by date of sowing International journal of agricultural sciences 2014,10(2).

5. Md Tariqul Islam. Effects of high temperature on photosynthesis and yield in mungbean. Bangladesh $\mathrm{J}$ Bot 2015;44(3):451-454.

6. Malik AM, Farrukh S, Asghar A, Rana Ahmad FI. Effect of sowing dates and planting patterns on growth and yield of mungbean, Vigna radiata L. J. Agric. Res 2003,44(2).

7. Nisar Ahmed Soomro, Habibur Rahman Khan. Response of Mungbean genotypes to different dates of sowing in kharif season under Rainfed conditions. Asian Jounral of Plant Sciences 2003;2:377-379.
8. Pradeep Makone JG, Patel CK, Desai, Sevak Das, Virendra Pal, Paramar JK. Influence of weather parameters on summer greengram (vigna radiata (1.) Wilczek) at sardar krushinagar Journal of Agrometeorology 2015;17(1):142-144.

9. Rana, JavaIqbal, Muhamad Ahamd Bakhsh. Effect of sowing dates and planting patterns on growth and yield of mungbean. International Journal of Agriculture and biology 2006;8(3):363-365.

10. Singh G, Sekhon HS, Ram H, Gill KK, Sharma P. Effect of date of sowing on nodulation, growth, thermal requirement and grain yield of kharif mung bean genotypes, J. of Food Legumes 2010;23(2):132-134.

11. Taleei AR, Khoda-Bandeh N, Gholamie B. Effects of sowing date on grain yield, yield components and percentage of protein in green gram cultivars. [Persian] Iranian J. Agri. Sci 1999;29(4):751-758.

12. Vakeswaran V, Jerlin R, Selvaraju P, Bhaskaran M. Effect of time of sowing, spacing between plants and different fertilizer levels on green gram (vigna radiata $\mathrm{L}$. wilczek) in seed yield attributing characters. International Journal of Agriculture Science 2016;57(8):3147-3150.

13. Venkatshwarulu MS, Soundara Rajan MS. Influence of season on growth and yield attributes of black gram. Indian J. Agronomy 1991;36:119-123. 